\title{
ダイコクネズミ睪丸に対する焦性ブドウ酸ナトリウム 及びコハク酸ナトリウムの効果
}

中谷洋一・本間運隆

(名古屋大学農学部)

\section{1. まえがき}

生体外に取り出した睪丸の代謝に関してはすでにいく つかの報告1 3) がある。本間4) 恃成長に伴了睪丸の分化 と代謝の関係をしらべ，睪丸重量の增加に伴う解糖能及 び呼吸能は 60 日令以前に顕著な低下がみとめられその 後はほぼ一定值にとどまうたと報告し, 著者5)等はダイ コクネズミ精細管の解糖能ならびに酸素消費を $38^{\circ} \mathrm{C}$ 及 び $28^{\circ} \mathrm{C}$ で測定し， $Q_{10}$ は幼若動物の解桾能が約 3 を示 したが，正常動物の呼吸能, 解糖能共約 2 であつたと報 告した。今回吾々はin vitro でのダイコクネズミ箤丸 （精細管）の酸素消費を測定し, 基質として焦性ブドウ 酸ナトリウムならびにコハク酸ナトリウムを使つた場合 ぞのような影響をうけるかについて検討し若干の知見を 得たので報告する。

\section{2. 実験動物ならびに実験方法}

実験動物は自家繁殖させた Wistar 系ダイコクネズミ の生後 2 週令より 12 カ月令までのるのを用いた。酸素 消費の測定は $37.5^{\circ} \mathrm{C}$ の恒温槽で行い，浮遊液は Krebs Ringer phosphate ${ }^{6}$ （pH 7.4）を用い，気相を空気と してWarburg 検圧計で測定した。

基質としては終末濃度 $\mathrm{M} / 100$ になるように焦性ブド ウ酸ナトリウムをWarburg 容器の側室に入れ，15 分 間の preincubation の後に浮遊液の中へ加えた。阻害実 験の場合にはマロン酸ナトリウムを終末濃度 $\mathrm{M} / 100$ に なるよ5に浮遊液の中に, あらかじめ加光, 15 分間の preincubation を行つた後基質を側室より加えた。

動物はと殺後直ちに睪丸を取り出し，トーションバラ ンスで一側ずつ科量し，更に精細管を取り出し 50〜100 $\mathrm{mg}$ を氷冷した Warburg 容器に移しピンセットの先で 各精細管を分離した。

酸素消費の測定は UMBREIT 等6) 及び吉川7) の方法

Effect of pyruvate and succinate on the respiration of rat testis. NAKATANI, Y. \& K. HoMmA (Fac. Agr., Nagoya Univ.) Jap.J. Animal Reprod. 4, (4).
に準じて行なつた。

\section{3. 測定結果}

1. 焦性ブドウ酸ナトリウムならびにコハク酸ナトリ ウムの影響

正常な発育をしたダイコクネズミの endogenous respiration は新鮮重量 $100 \mathrm{mg}$ 当り 1 時間の酸素消費に換 算して第 1 図に示す通りであり，一側の睪丸重量が約

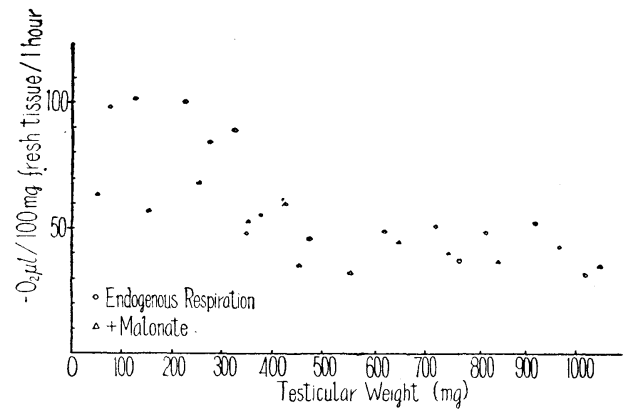

第 1 図

300mg に達するまでの幼若期に括ける酸素消費は 90〜 $100 \mu l$ を示しているが，その後睪丸重量が $400 \mathrm{mg}$ に発

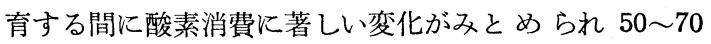
$\mu l$ になる。この結果は本間)の報告に略一致している。 ちょうどこの時期に達すると顕微鏡下に精子の出現がみ とめられる。又基質として焦性ブドウ酸ナトリウム及び

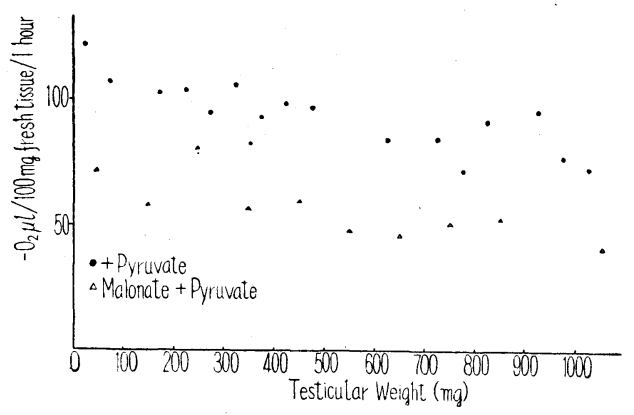

第 2 図 


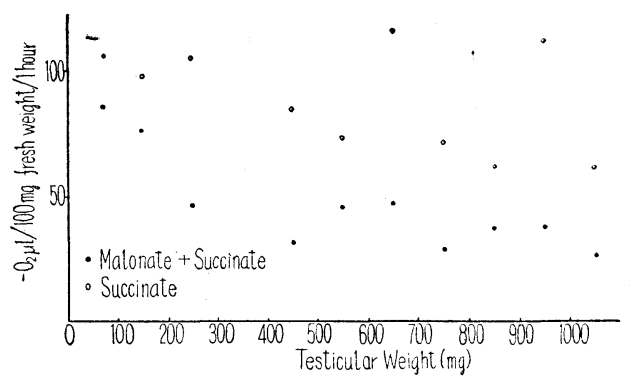

第 3 図

コハク酸ナトリウムを添加した場合は第 2 図及び第 3 図 に示してあるが，これらの基質の利用度は顕微鏡下で精 子の出現のみとめられる時期を大体の境として, その前 後で相異がみとめられる。即ち精子形成が開始された後 では基質の利用が非常に顕著であるが，等丸が末だ陰褧 内へ下降しない時期，即七生後 50〜60 日令に達するま では基質の利用があまり旺盛でない。

2. マロン酸ナトリウムによる阻害効果

マロン酸ナトリウムを添加し，これによる酸素消热の 阻害効果は第 2 図及び第 3 図に示寸通りである。測定 に当つてはマロン酸ナトリウムを浮遊液の中にあらかじ め加え 15 分間の preincubationをした後に侧䒧より基 質を加え酸素消費を測定した。15 分間の preincubation は予備実験の結果少くとも15 分間の preincubationを しなければマロン酸ナトリウムの阻害効果をみることが 出来なかつたからである。この結果をみると基質に焦性 ブドウ酸ナトリウム及びュハク酸ナトリウムを用いた場 合酸素消費量はマロン酸ナトリウムを添加しない場合の 大体 $50 \%$ 近くまで阻害効果を示している。この level は endogenous respiration の level である。

\section{4. 考 察}

正常な発育をして来たダイコクネズミの睪丸は一側の 重量が $200 \sim 300 \mathrm{mg}$ に達する時期, 即ち $50 \sim 60$ 日令 になると，顕微鏡下に精子の存在がみとめられ，睪丸 の陰囊への下降が起り, endogenous respiration に変
化が起り, 且焦性ブドウ酸ナトリウムやュハク酸ナトリ ウム等の基質の利用度にも変化を生じて来る。又 endogenous respiration に対するマロン酸ナトリウムの阻 害実験によれば，幼若期に於ける阻害効果はほぼ $50 \%$ を示し，成長が進み等丸重量が増加するにつれてその効 果は徐々に減少し, 造精が起り, 生殖可能な時期に達し た後は阻害効果がみとめられない。更に焦性ブドウ酸ナ トリウム及びュハク酸ナトリウムを基質として加えた時 はマロン酸ナトリウムによる阻害は大略 $50 \%$ 程度であ り, endogenous respiration の level までの阻害を示 す。これらの結果より正常に成長しているダイコクネズ ミの睪丸は生殖可能になつた時から生殖機能の停止する までの間はコハク酸ナトリウムを利用する代謝経路を通 つている事が推定出来る。

\section{5. 要 約}

ダイコクネズミ害丸の酸素消費を幼若期より成長にし たがい測定した。基質としては焦性ブドウ酸ナトリウム 及びュハク酸ナトリウムを用いた。尚マロン酸ナトリウ ムによる阻害の状態もあわせ測定した。一側の睪丸重量 が 200 300mg に遠ると基質の利用状況に変化が起 り，、ロン酸ナトリウムの添加により酸素消費は約50\% の阻些の起る事が観祭され, 生殖可能になつた時期から 生殖機能の停止するまでの間ではコハク酸ナトリウムを 利用する代謝経路を通つている事が推定された。

(1958. 10. 30. 受付)

\section{文献}

1) Tepperman, J. \& H. M. Tepperman : Endocrinol. 45, 491, 1949. 2) TEPPERMAN, H. M. \& J. TEPPERMAN : ibid. 47, 459, 1950. 3) HOMMA, K. : Bull. Naniwa Univ. B. 2,7,1952. 4) 本間 (運)：日畜会報. $24,28,1951.5$ ） 中谷(洋) - 本間 （運）：本誌 2,11,1956. 6) UMBREIT, W. W. et al. : Manometric techniques and tissue metabolism. 2nd Ed. 119, Pub. Co. Minneapolis, Minn. 1949. 7) 吉 川 (春)・他：化学の领域增刊 13, ワールブルグ検圧計 南汇堂, 1954. 